\title{
Catalytic Oxidation of Ponceau 4R in Aqueous Solution using Iron-impregnated Al-pillared Bentonite: Optimization of the Process
}

\author{
Paula Andrea Henao-Aguire ${ }^{1}$, Iván Fernando Macías-Quiroga ${ }^{1}$, Gloria Inés Giraldo-Gómez², \\ Nancy Rocío Sanabria-González ${ }^{1, *}$
}

${ }^{1}$ Department of Chemical Engineering, Faculty of Engineering and Architecture, Universidad Nacional de Colombia sede Manizales, Campus La Nubia, km 7 Via al Aeropuerto, AA 127 Manizales, Colombia. ${ }^{2}$ Department of Physics and Chemical, Faculty of Exact and Natural Sciences, Universidad Nacional de Colombia sede Manizales, Campus La Nubia, km 7 Via al Aeropuerto, AA 127 Manizales, Colombia.

Received: $6^{\text {th }}$ April 2021; Revised: 8th June 2021; Accepted: 9th June 2021 Available online: 11 st June 2021; Published regularly: September 2021

\section{Abstract}

The application of the Fenton-like process for the oxidation of an aqueous solution of Ponceau 4R dye, using an aluminum pillared clay impregnated with iron (Fe(wt\%)/Al-PILC) as catalyst, was investigated. The Response Surface Methodology (RSM), based on a Central Composite Design (CCD) was used to evaluate and optimize the oxidation process of a Ponceau $4 \mathrm{R}$ solution. Three independent variables were studied in the experimental design: the amount of $\mathrm{H}_{2} \mathrm{O}_{2}$ expressed in multiples of times of stoichiometry dose, iron concentration incorporated by impregnation onto aluminum pillared clay ( $\mathrm{Fe}(\mathrm{wt} \%)$ ), and amount of catalyst (Fe(wt\%)/Al-PILC). The response variables were decolorization and total organic carbon (TOC) removal. The significance of independent variables and their interactions were tested by means of analysis of variance (ANOVA), with a 95\% confidence level. With low stoichiometric dose of $\mathrm{H}_{2} \mathrm{O}_{2}$ (0.96 and 1.54 times), medium amount of catalyst (374.4 and $\left.391.3 \mathrm{mg}\right)$ and high $\mathrm{Fe}$ concentration impregnated in pillared clay (9.3 and $7.7 \mathrm{wt} \%)$, the total decolorization and high TOC removal were achieved. Under multi-objective optimization conditions (3.0 times the stoichiometric dose of $\mathrm{H}_{2} \mathrm{O}_{2}, 420 \mathrm{mg}$ $\mathrm{Fe}(\mathrm{wt} \%) / \mathrm{Al}-\mathrm{PILC}$ and $5.5 \mathrm{wt} \% \mathrm{Fe}$ impregnated in Al-PILC), it was possible to achieve $86.18 \%$ decolorization and $66.81 \%$ TOC removal after $5 \mathrm{~h}$ of reaction at $25^{\circ} \mathrm{C}$, with the additional advantage of showing an iron leaching of less than $0.10 \mathrm{mg} / \mathrm{L}$. The established models' soundness is confirmed by a good fit between predictive models and experimental results.

Copyright (C) 2021 by Authors, Published by BCREC Group. This is an open access article under the CC BY-SA License (https://creativecommons.org/licenses/by-sa/4.0).

Keywords: Fenton like; Pillared Clay; Ponceau 4R; Decolorization; Experimental Design

How to Cite: P.A. Henao-Aguire, I.F. Macías-Quiroga, G.I. Giraldo-Gómez, N.R. Sanabria-González (2021). Catalytic Oxidation of Ponceau 4R in Aqueous Solution using Iron-impregnated Al-pillared Bentonite: Optimization of the Process. Bulletin of Chemical Reaction Engineering \& Catalysis, 16(3), 491-506 (doi:10.9767/bcrec.16.3.10757.491-506)

Permalink/DOI: https://doi.org/10.9767/bcrec.16.3.10757.491-506

\section{Introduction}

The minimization of water pollution is one of the main areas of scientific research. Water pollutants are varied in nature, including organic

\footnotetext{
* Corresponding Author.

Email: nrsanabriag@unal.edu.co (N. Sanabria-González); Telp: +57-6-8879300
}

and inorganic substances. Inorganic pollutants are mainly represented by heavy metals, while the organic range from chloroform (small molecule), to compounds such as dyes, phenols, surfactants, pesticides, and pharmaceuticals, among other $[1,2]$.

Advanced Oxidation Processes (AOPs) were first proposed in the 1980s for drinking water 
treatment, and later were widely studied for the treatment of wastewaters. The AOPs involve the generation of hydroxyl radicals $(\cdot \mathrm{OH})$, which can degrade most refractory organic compounds or increase wastewater biodegradability, as a treatment prior to an ensuing biological treatment $[3,4]$. Among the metals that are able to activate $\mathrm{H}_{2} \mathrm{O}_{2}$ and produce hydroxyl radicals in water, iron is the most frequently used. In the so-called Fenton process, $\mathrm{H}_{2} \mathrm{O}_{2}$ reacts with $\mathrm{Fe}^{2+}$ ions to generate strong reactive species $[5,6]$. The generally accepted free radical chain mechanism for the Fenton reaction is summarized in Equations (1)-(3), while the slow reaction (Equation (2)) becomes a rate-determining step of the Fenton reaction [7-9]:

$$
\begin{aligned}
& \mathrm{Fe}^{2+}+\mathrm{H}_{2} \mathrm{O}_{2} \rightarrow \mathrm{Fe}^{3+}+\cdot \mathrm{OH}+\mathrm{OH}^{-} \\
& \mathrm{Fe}^{3+}+\mathrm{H}_{2} \mathrm{O}_{2} \rightarrow \mathrm{Fe}^{2+}+\mathrm{HO}_{2} \cdot+\mathrm{H}^{+} \\
& \mathrm{OH}+\mathrm{H}_{2} \mathrm{O}_{2} \rightarrow \mathrm{HO}_{2} \cdot+\mathrm{H}_{2} \mathrm{O}
\end{aligned}
$$

The Fenton reaction can take place in one or two phases, the first called homogeneous, where all the chemical species are in the aqueous phase; and the second, called heterogeneous, which uses a solid catalyst that supports the active iron phase or is immobilized on any material. The homogeneous Fenton process has, as a disadvantage, the sludge generation, the limited $\mathrm{pH}$ range and the hard iron ion recovery in solution [10-12]. The catalysts developed for the heterogeneous Fenton process are formed by an iron-containing active phase supported on material such as alumina [13], silica [14], zeolites [13,15], activated carbon [16], or pillared clays $[17,18]$.

The pillaring procedure involves the formation of aluminum polymeric species (mainly $\mathrm{Al}_{13}$ Keggin), intercalation of these species and a subsequent fixation of aluminum polyoxocations among clay layers [19,20]. In the last years, the suitability of aluminum pillared clays (Al-PILC) as a catalytic support of different transition metals has been explored [20,21], especially because of their higher surface area and microporosity [22].

The a zo-dye $\quad \mathrm{Ponceau} \quad 4 \mathrm{R}$ $\left(\mathrm{C}_{20} \mathrm{H}_{11} \mathrm{~N}_{2} \mathrm{O}_{10} \mathrm{~S}_{3} \mathrm{Na}_{3}\right)$, also known as acid red 18 , new coccine, additive E124 and CI 16255, is widely used to give red coloring to foodstuffs [23], especially in the confectionary industry [24]. Studies on treating water contaminated with sulfonic azo dyes are limited [25]. The degradation of Ponceau $4 \mathrm{R}$ by applying AOPs has been carried out using homogeneous Fenton [26], electro-Fenton [23], UVA photoelectroFenton [27], photoelectro-Fenton processes
$[23,27]$ and bicarbonate activated hydrogen peroxide in a Fenton-like reaction with $\mathrm{Co}(\mathrm{II})$ ions as the catalyst [28]. However, there are no studies in the accessed scientific literature on oxidation of Ponceau 4R using Catalytic Wet Peroxide Oxidation (CWPO) with a supported iron-based catalyst, where the support is a pillared clay. CWPO (Fenton-like process) is considered to be a low-cost technology because it can be operated without lamps (leading to reduction of electrical consumption) and work under mild conditions, such as: ambient temperature and atmospheric pressure [29].

In this study, the decolorization and total organic carbon (TOC) removal of aqueous solutions of Ponceau 4R by a Fenton-like process, using an aluminum pillared clay impregnated with iron ( $\mathrm{Fe}(\mathrm{wt} \%) / \mathrm{Al}-\mathrm{PILC})$ as catalyst was investigated. The effect of the amount of $\mathrm{H}_{2} \mathrm{O}_{2}$ (expressed as times of the stoichiometric dose, SD), amount of catalyst, weight percentage of Fe impregnated in Al-PILC and their interactions were evaluated using a Central Composite Design (CCD) combined with a Response Surface Methodology (RSM). Additionally, the optimal reaction conditions to achieve the maximum decolorization and TOC removal were obtained and experimentally validated. At these conditions, a kinetic study was performed and experimental data fitted to the Fermi's equation.

\section{Materials and Methods}

\subsection{Chemicals and Source Material}

All chemicals used in this work were of analytical grade. $\quad \mathrm{AlCl}_{3} .6 \mathrm{H}_{2} \mathrm{O} \quad(>97 \%)$, $\mathrm{Fe}\left(\mathrm{NO}_{3}\right)_{3} .9 \mathrm{H}_{2} \mathrm{O}(>98 \%)$ and $\mathrm{H}_{2} \mathrm{SO}_{4} \quad(95-98 \%)$ were supplied by Merck KGaA (Darmstadt, Germany). Hydrogen peroxide $\left(\mathrm{H}_{2} \mathrm{O}_{2} 30 \% \mathrm{w} / \mathrm{v}\right.$ solution), $\mathrm{NaCl}(>99 \%)$ and $\mathrm{NaOH}(>98 \%)$ were supplied by Panreac (Barcelona, Spain). The azo-dye Ponceau $4 \mathrm{R}\left(\mathrm{C}_{20} \mathrm{H}_{11} \mathrm{~N}_{2} \mathrm{O}_{10} \mathrm{~S}_{3} \mathrm{Na}_{3}, 604.48\right.$ g/mol, CAS registry number: 2611-82-7) was a food color (purity 89\%) supplied from Retema S.A.S.-Colombia. The stock solution $(25 \mathrm{mg} / \mathrm{L})$ was arranged by accurately dissolving a weighed quantity of the dye in distilled/deionized water. Distilled/deionized water was used for the preparation of all solutions.

The raw bentonite was collected from a mine in the municipality of Armero-Guayabal, Colombia, a mine exploited by the company GeaMinerales S.A.S. The mineralogical and chemical composition of this bentonite has been previously reported [30]. The bentonite was purified by conventional sedimentation fol- 
lowing Stokes' law and the fraction $\leq 2 \mu \mathrm{m}$ was denoted Bent [31]. The fraction $\leq 2 \mu \mathrm{m}$ was exchanged three times with a $0.1 \mathrm{M} \mathrm{NaCl}$ solution, washed with distilled water until removal of chloride ions (negative test with $\mathrm{AgNO}_{3}$ ), dried at $60{ }^{\circ} \mathrm{C}$ and finally ground and passed through a sieve $(125-150 \mathrm{~mm})$. The sodium bentonite purified (denoted $\mathrm{Na}^{+}$-Bent) had a cation exchange capacity (CEC) of 63.02 $\mathrm{mmol} / 100 \mathrm{~g}$ clay, determined by the ammonium acetate method.

\subsection{Synthesis of the Aluminum Pillared Clay}

The pillaring clay process was carried out following a standard procedure widely reported in the literature [32-35]. The pillaring aluminum solution was prepared by dropwise addition of $0.2 \mathrm{~mol} / \mathrm{L} \mathrm{NaOH}$ solution into a solution of $0.2 \mathrm{~mol} / \mathrm{L} \mathrm{AlCl} 3.6 \mathrm{H}_{2} \mathrm{O}$, maintaining a hydrolysis ratio $\mathrm{OH}^{-}: \mathrm{Al}^{3+}$ at 2.2 . Once hydrolysis was completed, the pillaring aluminum solution was aged for $4 \mathrm{~h}$ at $60^{\circ} \mathrm{C}$, under magnetic stirring at $200 \mathrm{rpm}$. To the $\mathrm{Na}^{+}$-Bent dispersed in distilled water $(20 \mathrm{~g} / \mathrm{L})$ for $12 \mathrm{~h}$, the pillaring solution $\left(\mathrm{Al}^{3+}: \mathrm{Na}^{+}\right.$-Bent ratio of $\left.10 \mathrm{mmol} / \mathrm{g}\right)$ was added, and the mixture was then stirred for 12 $\mathrm{h}$ at room temperature $\left(20 \pm 2{ }^{\circ} \mathrm{C}\right)$. The intercalated bentonite was repeatedly rinsed with distilled/deionized water until the supernatant liquid was free from chlorides (negative test with $\mathrm{AgNO}_{3}$ ). Finally, the sample was dried at $60^{\circ} \mathrm{C}$, ground, passed through a sieve $(125-150 \mathrm{~mm})$, and calcined at $400{ }^{\circ} \mathrm{C}\left(1{ }^{\circ} \mathrm{C} / \mathrm{min}\right)$ for $2 \mathrm{~h}$ to obtain the aluminum pillared bentonite, called Al-PILC.

\subsection{Synthesis of the Catalysts}

The catalysts were prepared with Al-PILC as support, and solution of $\mathrm{Fe}\left(\mathrm{NO}_{3}\right)_{3} .9 \mathrm{H}_{2} \mathrm{O}$ as $\mathrm{Fe}$ (III) precursor, by means of the incipient wetness impregnation (IWI) method [18]. The amount of salt needed for obtaining the weight percentage of iron in the final catalyst was dissolved in a minimum volume of water to completely soak the Al-PILC sample. After impregnation, the water was allowed to evaporate and samples dried at $60{ }^{\circ} \mathrm{C}$ for $24 \mathrm{~h}$. The obtained samples were then calcined at $400{ }^{\circ} \mathrm{C} \quad(1$ ${ }^{\circ} \mathrm{C} / \mathrm{min}$ ) in air for $2 \mathrm{~h}$. The catalysts were called $\mathrm{Fe}(\mathrm{wt} \%) / \mathrm{Al}-\mathrm{PILC}$, where wt.\% corresponds to the weight percentage of iron impregnated.

\subsection{Characterizations}

$\mathrm{Na}^{+}$-Bent, Al-PILC and Fe(wt\%)/Al-PILC were characterized by X-ray fluorescence (XRF), X-ray diffraction (XRD) and $\mathrm{N}_{2}$ adsorp- tion-desorption at $77 \mathrm{~K}$. The XRF analyses were performed using a Philips Magix Pro PW2440, with samples prepared as pearls. XRD patterns were obtained on a Rigaku Miniflex II Diffractometer, with $\mathrm{Cu}-\mathrm{Ka}$ radiation at $30 \mathrm{kV}$ and $15 \mathrm{~mA}$, steps of $0.05^{\circ} 2 \theta$ and 2 s/step. The XRD analyzes for the samples were performed with preferred oriented on a glass slide in the range from 3 to $15^{\circ} 2 \theta$ (a few drops of the samples suspension were smeared on a glass slide which was left to dry at room temperature) and with randomly oriented in the range of 3 to $60^{\circ} 2 \theta$ (the powder sample surface is pressed with a glass plate). The textural characterization of samples was carried out by $\mathrm{N}_{2}$ adsorption-desorption isotherms at $77 \mathrm{~K}$, using a Micromeritics ASAP 2020. The samples were previously degassed at $90{ }^{\circ} \mathrm{C}$ for $20 \mathrm{~h}$. Specific surface area $\left(S_{\mathrm{BET}}\right)$ was determined according to the Brunauer, Emmett and Teller equation, and the total pore volume $\left(\mathrm{V}_{\mathrm{t}}\right)$ was evaluated for nitrogen uptake at a relative pressure of 0.99. Microporous specific surface area $\left(S_{\text {microp }}\right)$ was calculated using the $t$-method of the Harking-Jura equation [36,37].

\subsection{Catalytic Experiments}

Prior to oxidation tests, batch adsorption experiments of Ponceau 4R dye $(300 \mathrm{~mL}, 25$ $\mathrm{mg} / \mathrm{L}, \mathrm{pH}=3.6$ and $25^{\circ} \mathrm{C}$ ) with $500 \mathrm{mg}$ of $\mathrm{Fe}(\mathrm{wt} \%) / \mathrm{Al}-\mathrm{PILC}$ and stirring constant at 200 $\mathrm{rpm}$ were carried out for $5 \mathrm{~h}$. It was found that the adsorption of the dye stabilized after 30 min of contact time, with values between $0.85 \pm 0.22,1.37 \pm 0.40$, and $2.68 \pm 1.12 \%$ for $\mathrm{Al}-$ PILC impregnated with $\mathrm{Fe}$ at 2.5, 5.5, and 8.5 wt\%, respectively. For all oxidation tests, an adsorption time of $30 \mathrm{~min}$ was established. The concentration of the dye after adsorption was measured and considered as initial concentration $\left(C_{0}\right)$ to oxidation tests.

All oxidation experiments were performed in a jacketed batch reactor with a capacity of $500 \mathrm{~mL}$, under constant stirring at $200 \mathrm{rpm}$, connected to a thermostatic water bath to keep the temperature constant at $25 \pm 0.1{ }^{\circ} \mathrm{C}$. For every experiment, the reactor was loaded with $300 \mathrm{~mL}$ of a Ponceau $4 \mathrm{R}$ aqueous solution at 25 $\mathrm{mg} / \mathrm{L}(0.0414 \mathrm{mM})$ and a defined amount of catalyst $(\mathrm{mg})$ to carry out the adsorption process for $30 \mathrm{~min}$, with a controlled $\mathrm{pH}$ at 3.6. Subsequently, a flux of $10 \mathrm{~L} / \mathrm{h}$ of dry air and $7 \mathrm{~mL}$ of $\mathrm{H}_{2} \mathrm{O}_{2}$ solution was dosed up in a peristaltic pump $(1.0 \mathrm{~mL}$ at $t=0$ and then a flow of 2 $\mathrm{mL} / \mathrm{h}$ ). The time of each test was $5 \mathrm{~h}$ (not including the time of dye adsorption). The $\mathrm{pH}$ of the reaction medium was adjusted at 3.6 with 
solutions $0.05 \mathrm{~mol} / \mathrm{L}$ of $\mathrm{H}_{2} \mathrm{SO}_{4}$ or $\mathrm{NaOH}$. This $\mathrm{pH}$ value was used in a previous study of textile azo-dye oxidation with delaminated montmorillonite with iron(III)- $\mathrm{TiO}_{2}$ species [38]. $\mathrm{pH}$ values between 3.0-4.0 have shown good results in the CWPO of phenol and orange II using pillared clays with iron [18,33,39]. In addition, in more than half of the studies on CWPO of industrial wastewater, the initial $\mathrm{pH}$ of the wastewater was adjusted to 3-4 [40].

The amount of $\mathrm{H}_{2} \mathrm{O}_{2}$ used was established based on the theoretically needed amount to completely mineralize $1 \mathrm{~mol}$ of the Ponceau 4R according to the Equation (4):

$$
\begin{aligned}
& \mathrm{C}_{20} \mathrm{H}_{11} \mathrm{~N}_{2} \mathrm{O}_{10} \mathrm{~S}_{3} 3^{-}+51 \mathrm{H}_{2} \mathrm{O}_{2} \rightarrow \\
& \quad 20 \mathrm{CO}_{2}+54 \mathrm{H}_{2} \mathrm{O}+2 \mathrm{NO}_{3}+3 \mathrm{SO}_{4}^{2-}+5 \mathrm{H}^{+}
\end{aligned}
$$

The stoichiometric dose (SD) $\mathrm{H}_{2} \mathrm{O}_{2}$ :Ponceau 4R corresponded to a 51:1 molar ratio. There is no rule to establish the dose of hydrogen peroxide necessary for the oxidation of an azo dye as this depends on the structure of the compound and, normally, an excess with respect to the stoichiometric dose is used [18,41,42].

The color removal was measured by monitoring the absorbance of dye in the aqueous medium at its respective maximum absorption wavelength $\left(\lambda_{\max }=507 \mathrm{~nm}\right)$ using a UV-Vis spectrophotometer (Mapada V-1200, China). The dye concentration was determined from aliquots $(1 \mathrm{~mL}$ of sample filtered in $0.45 \mu \mathrm{m}$ Millipore filter) taken at specific time intervals. The concentration intervals were from 0.5 to 30 $\mathrm{mg} / \mathrm{L}$, with a correlation coefficient $\left(\mathrm{R}^{2}\right)$ of 0.9998. Detection limit (DL) and quantification limit (QL) were $0.060 \mathrm{mg} / \mathrm{L}$ and $0.167 \mathrm{mg} / \mathrm{L}$, respectively. Decolorization was calculated from Equation (5), where $\mathrm{C}_{0}$ is the dye concentration at $t=0$ and $C_{t}$, the dye concentration at time $t$ :

$$
\operatorname{Decolorization}(\%)=\frac{C_{0}-C_{t}}{C_{t}} \times 100
$$

As the oxidation reactions were carried out with an excess of $\mathrm{H}_{2} \mathrm{O}_{2}$, between $0.4-1.0 \mathrm{~mL}$ sodium sulfite $(1.5 \mathrm{~mol} / \mathrm{L})$ was added at the end of the reaction $(t=5 \mathrm{~h})$ to instantaneously stop the reaction. This eliminates residual $\mathrm{H}_{2} \mathrm{O}_{2}$ that interferes with chemical oxygen demand (COD), total organic carbon (TOC) and total nitrogen (TN) measurements in Fenton processes [43-45]. Total organic carbon (TOC) removal or degree of mineralization was quantified by a TOC analysis at the beginning and, at the end of the reaction, using a Multi N/C 3100 TOC analyzer (Analytik Jena, Germany) equipped with a nondispersive infrared detector.

Calibration curves for TOC was obtained using standard solutions of potassium hydrogen phthalate $\left(\mathrm{C}_{8} \mathrm{H}_{5} \mathrm{KO}_{4}, \geq 99.5 \%\right.$, Merck, Darmstadt, Germany), with a detection limit of $4 \mu \mathrm{g} / \mathrm{L}$. TOC removal was determined by the Equation (6):

$$
\text { TOC removal }(\%)=\frac{T O C_{0}-T O C_{f}}{T O C_{f}} \times 100
$$

where $T O C_{o}$ and $T O C_{f}$ are the total organic carbon concentrations at $t=0$ and at the end of reaction $(t=5 \mathrm{~h})$. Iron leaching of the catalysts after $5 \mathrm{~h}$ of reaction was measured with a Thermo Scientific iCE 3000 Series atomic absorption spectrometer.

\subsection{Design of Experiments}

Optimum conditions for the oxidation of Ponceau $4 \mathrm{R}$ were determined by means of rotatable Central Composite Design (CCD). In this study, a $2^{3}$ full factorial CCD, with axial points $(\alpha= \pm 1.682)$ and replicates at the center point, was used for response surface modeling [46-48]. The matrix for the three variables of study, times of the stoichiometric dose of $\mathrm{H}_{2} \mathrm{O}_{2}$ $\left(\mathrm{X}_{1}\right)$, catalyst amount $\left(\mathrm{X}_{2}\right)$ and weight percentage of Fe impregnated in Al-PILC $\left(\mathrm{X}_{3}\right)$ was varied at five levels $(-\alpha,-1,0,+1,+\alpha)$. The response variables for the oxidation of Ponceau $4 \mathrm{R}$ were decolorization and TOC removal. All experiments were randomly performed to avoid a systematic error. Ranges considered for the three studied independent variables were chosen on the basis of previously performed experiments. The level and ranges of the studied variables are presented in Table 1 . Twenty experiments were carried out in order to produce this analysis, eight of which corresponded to the factorial design, six to axial points, and six

Table 1. Levels of independent variables used in the experimental design.

\begin{tabular}{lccccc}
\hline \multirow{2}{*}{ Variable } & \multicolumn{4}{c}{ Coded and Uncoded Levels } \\
\cline { 2 - 6 } & -1.682 & -1 & 0 & +1 & +1.682 \\
\hline $\mathrm{H}_{2} \mathrm{O}_{2}, \mathrm{SD}\left(X_{1}\right)$ & 0.95 & 3 & 6 & 9 & 11.05 \\
Catalyst amount, mg $\left(X_{2}\right)$ & 17.70 & 120 & 270 & 420 & 522.30 \\
Impregnated Fe, wt\% $\left(X_{3}\right)$ & 0.45 & 2.5 & 5.5 & 8.5 & 10.55 \\
\hline
\end{tabular}


to central points to ensure repeatability. The response surface methodology (RSM) was used for data analysis, which is a mathematical and statistical method that allows obtaining a model that correlates independent variables of the process on the response variable [49]. Therefore, the main goals of an RSM study are to understand the topography of the response surface and determine the region where the most appropriate response occurs [50]. The software Design Expert 8.0 (StatEase, Inc., Minneapolis, MN, USA) was used to design and analyze the experimental matrix, in order to measure the effect of the three factors on the decolorization and TOC removal.

For the concentration of $25 \mathrm{mg} / \mathrm{L}$ dye, three successive oxidation tests were carried out to evaluate its catalyst stability, at the optimum conditions of multi-objective optimization process. Between cycles, the catalyst was washed three times with distilled water and dried at $105^{\circ} \mathrm{C}$ for $6 \mathrm{~h}$.

\subsection{Kinetic Study}

At the optimal reaction conditions of decolorization and TOC removal (multi-objective optimization), a kinetic study was carried out by monitoring the normalized dye concentration evolution $\left(C_{t} / C_{0}\right)$ at three different temperatures $\left(25,35\right.$ and $\left.45^{\circ} \mathrm{C}\right)$ as function of time $(t)$.

\section{Results and Discussion}

\subsection{Characterization of Materials}

The elemental composition and summary of textural properties of sodium bentonite, aluminum pillared bentonite (support) and catalysts impregnated with iron are shown in Table 2. The aluminum content was increased after the
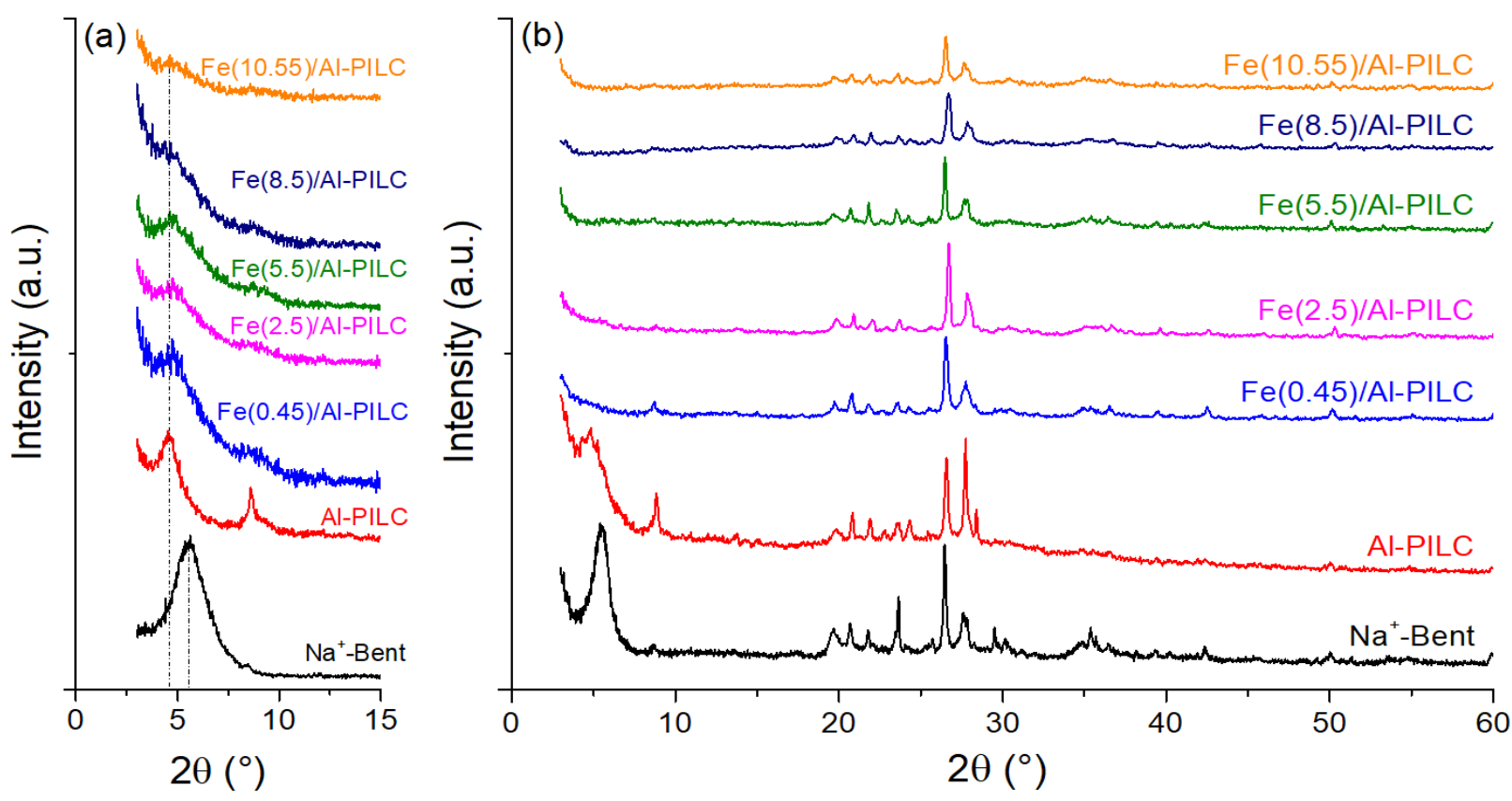

Figure 1. X-ray diffraction patterns of samples a) preferred orientation on a glass slide and b) randomly oriented - the sample surface was pressed with a glass plate.

Table 2. Elemental composition and textural properties of the samples.

\begin{tabular}{|c|c|c|c|c|c|c|c|c|}
\hline \multirow{2}{*}{ Sample } & \multicolumn{5}{|c|}{ Elemental content (wt\%) } & \multirow{2}{*}{$\begin{array}{c}S_{\mathrm{BET}} \\
\left(\mathrm{m}^{2} / \mathrm{g}\right)\end{array}$} & \multirow{2}{*}{$\begin{array}{l}S_{\text {microp }} \\
\left(\mathrm{m}^{2} / \mathrm{g}\right)\end{array}$} & \multirow{2}{*}{$\begin{array}{c}V_{\text {total }} \\
\left(\mathrm{cm}^{3} / \mathrm{g}\right)\end{array}$} \\
\hline & $\mathrm{Si}$ & $\mathrm{Al}$ & $\mathrm{Fe}$ & aFe added & $\mathrm{Na}$ & & & \\
\hline $\mathrm{Na}^{+}$-Bent & 25.87 & 8.62 & 5.25 & & 2.84 & 45.1 & 8.7 & 0.0447 \\
\hline Al-PILC & 23.64 & 11.52 & 4.45 & & 0.98 & 174.0 & 135.9 & 0.1127 \\
\hline $\mathrm{Fe}(0.45) / \mathrm{Al}-\mathrm{PILC}$ & 23.48 & 11.21 & 4.87 & 0.42 & 0.98 & 143.1 & 101.5 & 0.0954 \\
\hline $\mathrm{Fe}(2.5) / \mathrm{Al}-\mathrm{PILC}$ & 23.33 & 11.33 & 6.83 & 2.38 & 0.97 & 122.6 & 83.5 & 0.0902 \\
\hline $\mathrm{Fe}(5.5) / \mathrm{Al}-\mathrm{PILC}$ & 22.37 & 10.89 & 9.77 & 5.32 & 0.97 & 112.0 & 70.5 & 0.0713 \\
\hline $\mathrm{Fe}(8.5) / \mathrm{Al}-\mathrm{PILC}$ & 22.17 & 10.78 & 12.82 & 8.37 & 0.95 & 48.7 & 9.6 & 0.0418 \\
\hline $\mathrm{Fe}(10.55) / \mathrm{Al}-\mathrm{PILC}$ & 21.28 & 10.22 & 14.77 & 10.32 & 0.94 & 23.3 & 3.9 & 0.0211 \\
\hline
\end{tabular}

aAmount of Fe added in Al-PILC by incipient wetness impregnation method; $\mathrm{S}_{\text {BET: BET specific surface area; }} \mathrm{S}_{\text {microp: microporous }}$ specific surface area; $\mathrm{V}_{\mathrm{t}}$ : total pore volume. 
pillarization process, due to the exchange of $\mathrm{Na}^{+}$ions present in the $\mathrm{Na}^{+}$-Bent for aluminum polyhydroxocations contained in the pillaring solution [51]. The iron content decreased in AlPILC compared to $\mathrm{Na}^{+}$-Bent due to the considerable increase in the content of aluminum. In the catalysts prepared by IWI (called Fe (wt\%)/Al-PILC), the amount of experimental iron was lower than the theoretical amount of the precursor metal dissolved in the aqueous solution. The incorporation of Fe in the catalytic support was between 93.4 and $98.5 \%$, and the difference between theoretical and experimental values may be associated with the precision of the analytical method [52].

The X-ray diffraction patterns of sodium bentonite, aluminum pillared bentonite (support) and catalysts impregnated with iron are shown in Figure 1a, with a preferred orientation and, in Figure 1b, randomly oriented. The XRD pattern of Al-PILC (Figure 1a) show the effective introduction of aluminum polyhydroxocations and the subsequent formation of pillars in the interlaminar spacing [39]. The shift in do01 reflection for the basal spacing of $15.9 \AA\left(2 \theta=5.54^{\circ}\right)$ of the starting clay $\left(\mathrm{Na}^{+}\right.$Bent, air-dried at $\left.60^{\circ} \mathrm{C}\right)$ at $19.1 \AA\left(2 \theta=4.62^{\circ}\right)$ confirms the successful structural modification of the solid via pillaring (Al-PILC). The catalysts prepared by IWI with iron species did not exhibit, in the XRD patterns, the characteristic peaks of crystalline $\mathrm{Fe}_{2} \mathrm{O}_{3}$ or other forms of iron compounds (Figure 1b), indicating that the iron species were well dispersed on the support (AlPILC) or presented in an amorphous state [5355]. The catalysts impregnated with the iron precursor maintained the layered structure of the Al-PILC, with similar basal spacing (Figure 1a), but with a higher full width at half maxi-

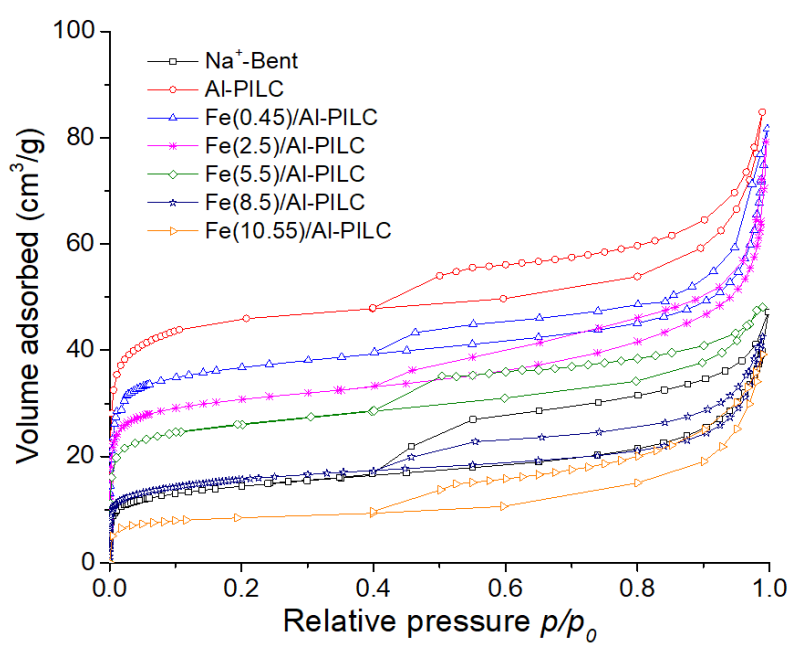

Figure $2 . \mathrm{N}_{2}$ adsorption-desorption isotherms of the samples. mum (FWHM) in the XRD profile, associated with loss of ordering if compared with the support [56]. The greater the amount of iron impregnated in the support, the intensity of the Al-PILC principal diffraction peak decreased due to the higher absorption coefficient of iron compounds for the X-ray radiation [54,57].

$\mathrm{N}_{2}$ adsorption-desorption isotherms at $77 \mathrm{~K}$ of sodium bentonite, aluminum pillared bentonite (support) and the catalysts impregnated with iron are shown in Figure 2. The pillaring process with aluminum led to changes in the texture of the Al-PILC regarding the $\mathrm{Na}^{+}$-Bent (Table 2), increasing the specific surface area, microporous area and total pore volume. $\mathrm{S}_{\text {BET }}$ increased from $45.1 \mathrm{~m}^{2} / \mathrm{g}$ in $\mathrm{Na}^{+}$-Bent to 174.0 $\mathrm{m}^{2} / \mathrm{g}$ in Al-PILC, which confirmed the textural modification of the support. However, after the impregnation process of the support with the iron precursor, it was found that the textural properties decreased with an increasing iron load, obtaining catalysts with lower specific surface and microporous areas. The preceding is attributed to the blockage of the iron species in the pores of the support [53] as well as to the additional steps of wetting-drying and calcination in the impregnated solids. Similar results in the decrease in $\mathrm{S}_{\mathrm{BET}}$ and microporous area for transition metals supported on Al-PILC, have been described $[22,53]$.

\subsection{Results of Catalytic Tests - Experimental Design}

The effects of the three independent variables on the response functions were studied using a central composite design and response surface methodology. Optimal reaction conditions that maximize decolorization and TOC removal were also determined. The codified and experimental values of runs performed in the experimental design, with the decolorization and TOC removal obtained, are shown in Table 3.

Data were adjusted to a second-order polynomial equation to determine the coefficients of the response model as well as its significance [58]. For the three variables input under consideration, the response model is shown in Equation (7):

$$
Y=\beta_{0}+\sum_{i=1}^{k} \beta_{i} X_{i}+\sum_{i=1}^{k} \beta_{i i} X_{i}^{2}+\sum_{i=1}^{k-1} \sum_{\substack{j=2 \\ j>i}}^{k} \beta_{i j} X_{i} X_{j}
$$

where $Y$ is the predicted response $\left(Y_{1}=\right.$ decolorization, and $Y_{2}=$ TOC removal), $\beta_{0}, \beta_{i}, \beta_{i i}$, and $\beta_{i j}$ are the regression coefficients for the intercept and the linear, quadratic and interaction 
Table 3. Coded and experimental values of the runs performed and results obtained in the oxidation of dye.

\begin{tabular}{|c|c|c|c|c|c|c|c|c|}
\hline \multirow[b]{2}{*}{ Run } & \multicolumn{3}{|c|}{ Coded values } & \multicolumn{3}{|c|}{ Experimental values } & \multicolumn{2}{|c|}{ Results (\%) } \\
\hline & $X_{1}$ & $X_{2}$ & $X_{3}$ & $X_{1}$ & $X_{2}$ & $X_{3}$ & $\begin{array}{c}\text { Decolorization } \\
\left(Y_{1}\right)\end{array}$ & $\begin{array}{c}\text { TOC removal } \\
\left(Y_{2}\right)\end{array}$ \\
\hline 9 & -1.682 & 0 & 0 & 0.954 & 270 & 5.5 & 91.80 & 63.89 \\
\hline 16 & 0.000 & 0 & 0 & 6 & 270 & 5.5 & 69.51 & 67.60 \\
\hline 10 & 1.682 & 0 & 0 & 11.05 & 270 & 5.5 & 58.26 & 45.41 \\
\hline 3 & -1 & 1 & -1 & 3 & 420 & 2.5 & 71.33 & 58.01 \\
\hline 12 & 0 & 1.682 & 0 & 6 & 522.3 & 5.5 & 78.97 & 71.18 \\
\hline 1 & -1 & -1 & -1 & 3 & 120 & 2.5 & 43.52 & 25.77 \\
\hline 19 & 0 & 0 & 0 & 6 & 270 & 5.5 & 70.23 & 63.70 \\
\hline 11 & 0 & -1.682 & 0 & 6 & 17.7 & 5.5 & 5.60 & 8.53 \\
\hline 7 & -1 & 1 & 1 & 3 & 420 & 8.5 & 93.76 & 70.32 \\
\hline 2 & 1 & -1 & -1 & 9 & 120 & 2.5 & 19.45 & 13.84 \\
\hline 5 & -1 & -1 & 1 & 3 & 120 & 8.5 & 76.27 & 58.19 \\
\hline 14 & 0 & 0 & 1.682 & 6 & 270 & 10.55 & 76.45 & 68.51 \\
\hline 13 & 0 & 0 & -1.682 & 6 & 270 & 0.45 & 10.90 & 11.70 \\
\hline 18 & 0 & 0 & 0 & 6 & 270 & 5.5 & 61.25 & 58.11 \\
\hline 20 & 0 & 0 & 0 & 6 & 270 & 5.5 & 68.37 & 48.63 \\
\hline 15 & 0 & 0 & 0 & 6 & 270 & 5.5 & 73.08 & 60.61 \\
\hline 8 & 1 & 1 & 1 & 9 & 420 & 8.5 & 91.62 & 69.62 \\
\hline 17 & 0 & 0 & 0 & 6 & 270 & 5.5 & 58.16 & 61.51 \\
\hline 6 & 1 & -1 & 1 & 9 & 120 & 8.5 & 56.86 & 48.76 \\
\hline 4 & 1 & 1 & -1 & 9 & 420 & 2.5 & 55.33 & 48.72 \\
\hline
\end{tabular}

Table 4. ANOVA results for decolorization (\%) - model and coefficients validation.

\begin{tabular}{lccccc}
\hline Source & Sum of squares & $d f$ & Mean square & $F$-value & $p$-value \\
\hline $\mathrm{X}_{1}$ & 1020.03 & 1 & 1020.03 & 13.22 & 0.0046 \\
$\mathrm{X}_{2}$ & 4194.26 & 1 & 4194.26 & 54.35 & $<0.0001$ \\
$\mathrm{X}_{3}$ & 4186.84 & 1 & 4186.84 & 54.26 & $<0.0001$ \\
$\mathrm{X}_{1} \mathrm{X}_{2}$ & 80.26 & 1 & 80.26 & 1.04 & 0.3318 \\
$\mathrm{X}_{1} \mathrm{X}_{3}$ & 42.87 & 1 & 42.87 & 0.56 & 0.4732 \\
$\mathrm{X}_{2} \mathrm{X}_{3}$ & 16.36 & 1 & 16.36 & 0.21 & 0.6551 \\
$\mathrm{X}_{1}{ }^{2}$ & 385.01 & 1 & 385.01 & 4.99 & 0.0495 \\
$\mathrm{X}_{2}{ }^{2}$ & 591.83 & 1 & 591.83 & 7.67 & 0.0198 \\
$\mathrm{X}_{3}{ }^{2}$ & 504.54 & 1 & 504.54 & 6.54 & 0.0285 \\
\hline Model & 11117.43 & 9 & 1235.27 & 16.01 & $<0.0001$ \\
Residual & 771.67 & 10 & 77.17 & & \\
Lack of fit & 605.21 & 5 & 121.04 & 3.64 & 0.0914 \\
Pure error & 166.46 & 5 & 33.29 & & \\
\hline Cor total & 11889.10 & 19 & & & \\
\hline $\mathrm{R}^{2}$ & 0.9351 & & & & \\
Adjusted $\mathrm{R}^{2}$ & 0.8767 & & & & \\
\hline
\end{tabular}


coefficients, respectively; $X_{\mathrm{i}}$ and $X_{\mathrm{j}}$ are the coded levels for independent variables, and $k=3$, i.e., the number of independent variables. The quality of the model fits was evaluated by the coefficients of determination $\left(\mathrm{R}^{2}\right.$ and adjusted $\mathrm{R}^{2}$ ) and analysis of variance (ANOVA) [59,60].

Analysis of variance (ANOVA) was applied for estimating the model significance. Results are shown in Table 4 for the decolorization response variable and, in Table 5, for the TOC removal response variable. A model is considered significant if the $p$-value $<0.05$ and, for this study, the two models showed a small probability value $(p<0.0001)$, indicating that the models were highly significant and could be used to accurately predict the response functions. From the $p$-values presented in Tables 4 and 5 , it can be stated that the linear terms $X_{1}, X_{2}$, and $X_{3}$, and quadratic terms $X_{2}{ }^{2}$ and $X_{3}{ }^{2}$ are significant in the two models. The quadratic term $X_{1}{ }^{2}$ was only significant for the decolorization response variable. Interaction terms $X_{1} X_{2}, X_{1} X_{3}$, and $X_{2} X_{3}$ were not significant in two response variables $\left(Y_{1}, Y_{2}\right)$.

The response functions with the determined coefficients for decolorization $\left(Y_{1}\right)$ and TOC removal $\left(Y_{2}\right)$ are presented in Equations (8) and (9):

$$
\begin{aligned}
Y_{1}(\%) & =15.25924-13.08764 X_{1}+0.24588 X_{2} \\
+ & 12.38290 X_{3}+7.03889 \times 10^{-3} X_{1} X_{2}+0.25722 X_{1} X_{3} \\
& -3.17778 \times 10^{-3} X_{2} X_{3}+0.57430 X_{1}^{2}-2.84817 \times 10^{-4} X_{2}^{2} \\
& -0.65744 X_{3}^{2}
\end{aligned}
$$

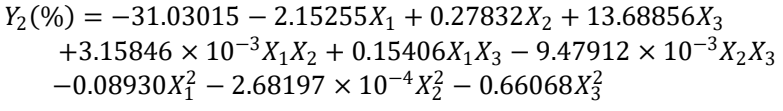

Based on the coefficients given in Equations (8) and (9), the amount of iron impregnated in $\mathrm{Al}$ PILC $\left(X_{3}\right)$ showed the highest positive influence on the decolorization and TOC removal; i.e. increasing the amount of $\mathrm{Fe}$ impregnated in the support increased the decolorization and TOC removal. The amount of $\mathrm{H}_{2} \mathrm{O}_{2}$ expressed as a function of the stoichiometric dose (SD) had a negative effect on decolorization and TOC removal, thus increasing the $\mathrm{H}_{2} \mathrm{O}_{2}$ SD results in less degradation of the dye solution. This may be due to the inhibitory effect of excessive $\mathrm{H}_{2} \mathrm{O}_{2}$ (hydroxyl radical scavenging) which can be expressed by the reaction described in Equation (10) [61,62]:

$$
\mathrm{H}_{2} \mathrm{O}_{2}+\cdot \mathrm{OH} \rightarrow \mathrm{H}_{2} \mathrm{O}+\mathrm{HO}_{2} \cdot
$$

The positive effect of the amount of catalyst $\left(X_{2}\right)$ on the response variables $Y_{1}$ and $Y_{2}$ was also found to be significant, although the effect was lower than the other variables studied. A positive factor effect is an improved response when the factor level increases, and a negative factor effect is an inhibited response when the factor level increases [63]. The coefficients of determination $\left(\mathrm{R}^{2}\right)$ and the adjusted $\mathrm{R}$-squared (adjusted $\mathrm{R}^{2}$ ) of the models were 0.9351 and 0.8767 for decolorization, and 0.9370 and

Table 5. ANOVA results for TOC removal (\%) - model and coefficients validation.

\begin{tabular}{lccccc}
\hline Source & Sum of squares & $d f$ & Mean square & $F$-value & $p$-value \\
\hline $\mathrm{X}_{1}$ & 285.47 & 1 & 285.47 & 5.80 & 0.0368 \\
$\mathrm{X}_{2}$ & 3091.79 & 1 & 3091.79 & 62.85 & $<0.0001$ \\
$\mathrm{X}_{3}$ & 2815.50 & 1 & 2815.50 & 57.23 & $<0.0001$ \\
$\mathrm{X}_{1} \mathrm{X}_{2}$ & 16.16 & 1 & 16.16 & 0.33 & 0.5792 \\
$\mathrm{X}_{1} \mathrm{X}_{3}$ & 15.38 & 1 & 15.38 & 0.31 & 0.5884 \\
$\mathrm{X}_{2} \mathrm{X}_{3}$ & 145.56 & 1 & 145.56 & 2.96 & 0.1161 \\
$\mathrm{X}_{1}{ }^{2}$ & 9.31 & 1 & 9.31 & 0.19 & 0.6728 \\
$\mathrm{X}_{2}{ }^{2}$ & 524.78 & 1 & 524.78 & 10.67 & 0.0085 \\
$\mathrm{X}_{3}{ }^{2}$ & 509.53 & 1 & 509.53 & 10.36 & 0.0092 \\
\hline Model & 7311.90 & 9 & 812.43 & 16.52 & $<0.0001$ \\
Residual & 491.93 & 10 & 49.19 & & \\
Lack of fit & 285.01 & 5 & 57.00 & 1.38 & 0.3670 \\
Pure error & 206.93 & 5 & 41.39 & & \\
\hline Cor total & 7803.93 & 19 & & & \\
\hline $\mathrm{R}^{2}$ & 0.9370 & \multicolumn{5}{c}{} \\
Adjusted $\mathrm{R}^{2}$ & 0.8802 & \multicolumn{5}{c}{} & \\
\hline
\end{tabular}


0.8802 , for TOC removal, respectively. These showed that the regression was statistically significant. It is suggested that the $\mathrm{R}^{2}$ must be at least $80 \%$ for the model to properly fit [64]. Only $6.49 \%$ and $6.30 \%$ of the total variations was not explained by the models of decolorization and TOC removal, respectively.

\subsection{Response Contour Plots and Optimization}

Employing RSM, two-dimensional contour (2D) plots, for the predicted responses $\left(Y_{1}, Y_{2}\right)$, were represented. Response contours for the decolorization and mineralization are shown in Figures 3 and 4 . For the decolorization response (Figure 3), it can be seen that, with low $\mathrm{H}_{2} \mathrm{O}_{2}$ SD, medium-high amounts of catalyst and a high amount of $\mathrm{Fe}$ impregnated in $\mathrm{Al}$ PILC (5.5 and 8.5 wt\%), a total decolorization are achieved. From the contour plots for TOC removal (Figure 4), as a function of $\mathrm{H}_{2} \mathrm{O}_{2} \mathrm{SD}$ and of the catalyst amount, it was observed that, at low and high $\mathrm{H}_{2} \mathrm{O}_{2} \mathrm{SD}$, medium-high amounts of catalyst and a higher amount of $\mathrm{Fe}$ impregnating the Al-PILC (5.5 and 8.5\%), TOC removals between $70-74 \%$ were obtained. The values achieved in decolorization of Ponceau $4 \mathrm{R}$ are higher than those obtained in TOC removal since for the color removal, the reactive oxygen species only have to break the bond $-\mathrm{N}=\mathrm{N}-[65]$. On the other side, for the removal of TOC, the dye must degrade in intermediates and reach $\mathrm{CO}_{2}$ and $\mathrm{H}_{2} \mathrm{O}$.

The catalytic decomposition of $\mathrm{H}_{2} \mathrm{O}_{2}$ by iron oxides for the generation of $\cdot \mathrm{OH}$ radicals, in heterogeneous media, has been described by Lin and Gurol [66]. The proposed reaction
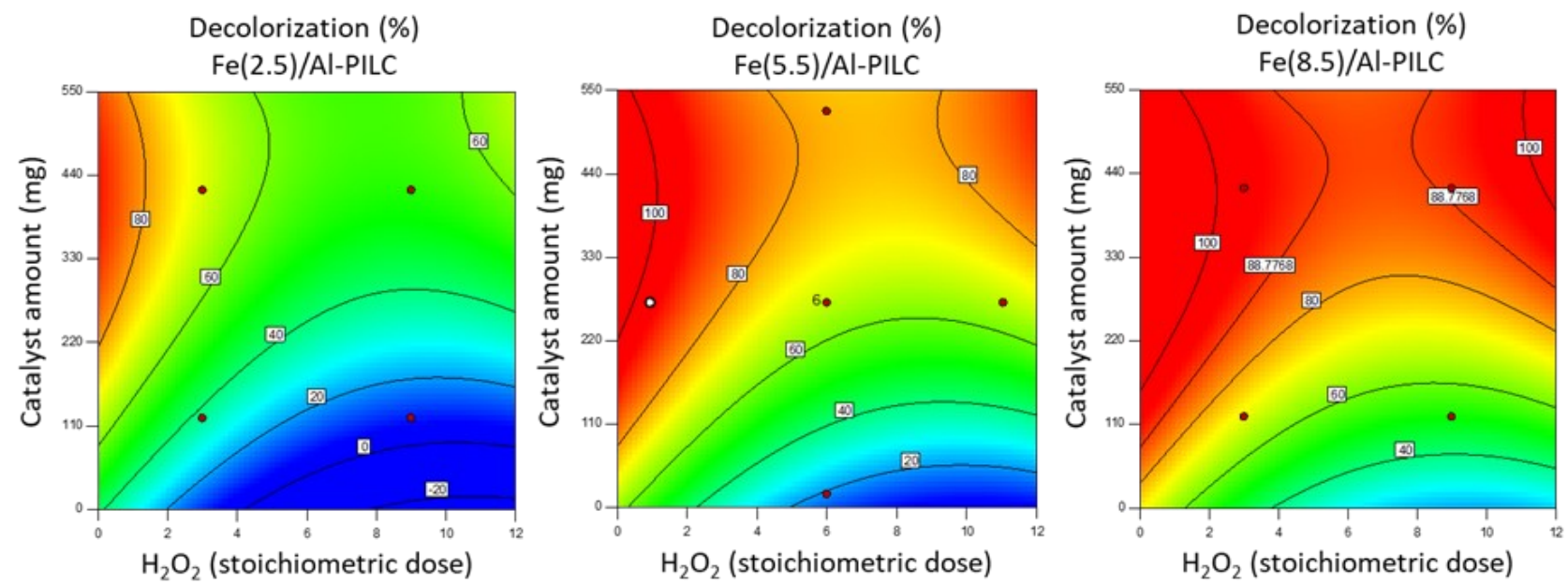

Figure 3. Contour plots for decolorization of ponceau $4 \mathrm{R}$ as a function of impregnated Fe amount (wt\%) on the support (Al-PILC). Condition of reaction: [Ponceau 4R] $=25 \mathrm{mg} / \mathrm{L}, \mathrm{pH}$ control $=3.6, \mathrm{~T}=25 \pm 0.1$ ${ }^{\circ} \mathrm{C}$, reaction time: $5 \mathrm{~h}$, stirring speed $=200 \mathrm{rpm}$.
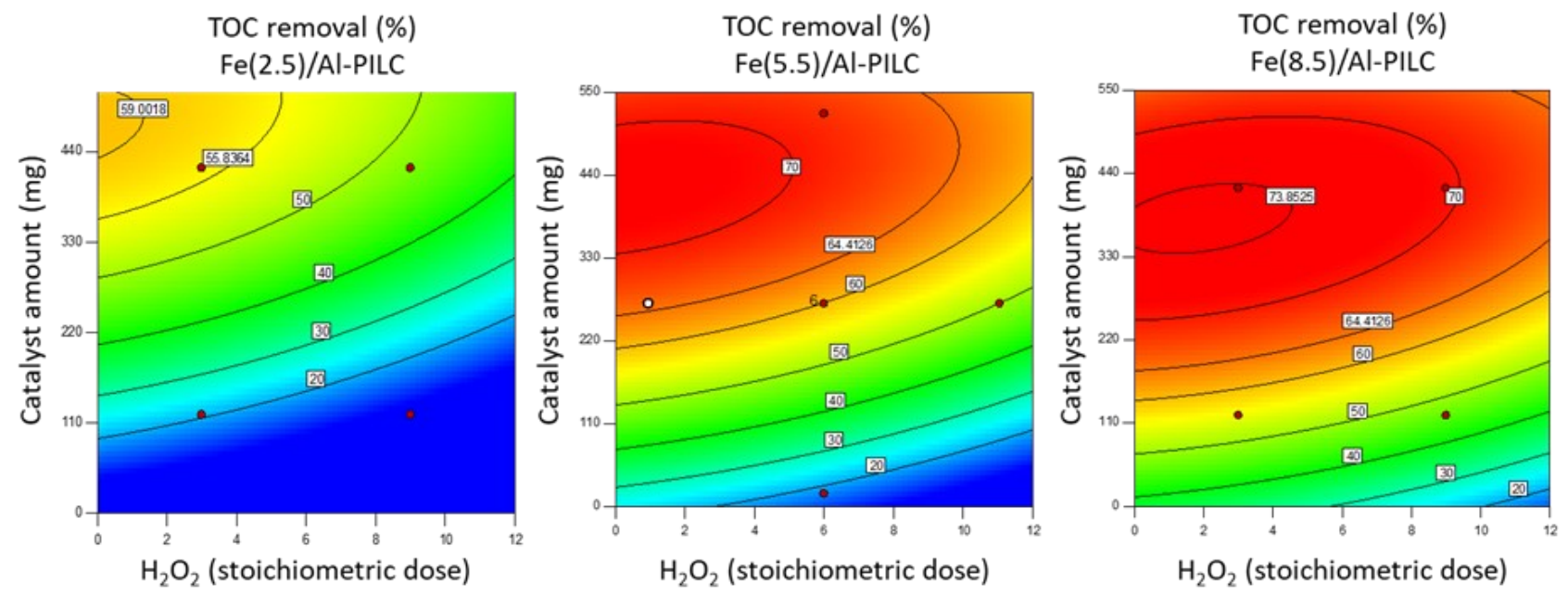

Figure 4. Contour plots for TOC removal as a function of impregnated $\mathrm{Fe}$ amount (wt\%) on the support (Al-PILC). Condition of reaction: $[$ Ponceau $4 \mathrm{R}]=25 \mathrm{mg} / \mathrm{L}, \mathrm{pH}$ control $=3.6, \mathrm{~T}=25 \pm 0.1{ }^{\circ} \mathrm{C}$, reaction time: $5 \mathrm{~h}$, stirring speed $=200 \mathrm{rpm}$. 
mechanism for the degradation of Ponceau red $4 \mathrm{R}$ by advanced oxidation processes shows that the main by-products are aromatic compounds and organic acids (tartaric, fumaric, maleic, propanoic, oxalic and formic acids), in addition to $\mathrm{CO}_{2}, \mathrm{H}_{2} \mathrm{O}$ and $\mathrm{NO}_{3}^{-}, \mathrm{NH}_{4}^{+}$, and $\mathrm{SO}_{4}^{2-}$ ions [23].

Decolorization and TOC removal achieved with the support (420 mg Al-PILC) and 3 times the $\mathrm{SD}$ of $\mathrm{H}_{2} \mathrm{O}_{2}$, was very low. At $5 \mathrm{~h}$ of reaction, a decolorization of $7.4 \pm 0.6 \%$ and TOC removal of $1.2 \pm 0.3 \%$ was achieved. This catalytic activity may be related to the iron content of Al-PILC (4.45 wt\% $\mathrm{Fe}_{2} \mathrm{O}_{3}$, Table 2). This iron is found in the octahedral layer of clay mineral or as iron oxide cluster on the bentonite surface, it has a low activity for $\mathrm{H}_{2} \mathrm{O}_{2}$ decomposition in the Fenton-like reaction.

For analyzing the stability of the catalysts, the leached iron concentration was measured at the end of the oxidation tests. For all oxidation tests, with the impregnating support with a low amount of iron (0.45, 2.5 and $5.5 \mathrm{wt} \%)$, the leached iron concentration was lower than $0.10 \mathrm{mg} / \mathrm{L}$. However, for Al-PILC impregnated with a higher amount of iron (8.5 and 10.55 $\mathrm{wt} \%$ ), the leached iron concentration varied between 0.14 and $0.32 \mathrm{mg} / \mathrm{L}$. In the degradation and mineralization of orange II solutions, using pillared saponite impregnated with several iron salts, it was found that, at $\mathrm{pH}=2.0$, the greatest leaching of the active phase occurred [17]. Furthermore, this catalyst exhibited a high activity in the oxidation of azo-dye, with very good stability and low iron leaching, always be- low 2 ppm [18]. In this study, a low iron leaching was found, especially when the concentration of Fe impregnated in Al-PILC, was equal to or lower than $5.5 \mathrm{wt} \%$. It indicated that the active phase of these catalysts was strongly fixed to the support, and that it is highly stable under conditions of the reaction [67].

For the mathematical optimization, the desired objectives of each process variable and response function should be previously established. Decolorization or TOC removal can be independently optimized, or a multi-objective optimization, combining the two response functions, can be performed. Table 6 summarizes the optimization results for decolorization, TOC removal and, simultaneously, the two response functions (multi-objective optimization).

In the present analysis, in the response function decolorization or TOC removal, "maximize" was selected; in the $\mathrm{H}_{2} \mathrm{O}_{2}$ dose, "minimize" and, in the amount of catalyst and Fe concentration impregnating, "in range" of study was chosen. At optimal decolorization conditions, the model predicts a value greater than $100 \%$, which is an error associated with the wide range of results covered by the second order polynomial model [68]. However, this value is in the error range of the model, which is $\pm 8.8 \%$. Optimum values for Al-PILCimpregnated $\mathrm{Fe}$ concentration, that maximize decolorization or TOC removal, were 9.3 and $7.7 \mathrm{wt} \%$, respectively. Experimental tests validating these optimization conditions found that the concentration of the leached iron ranged from 0.14 and $0.29 \mathrm{mg} / \mathrm{L}$.

Table 6. Comparison of predictive and experimental results - Optimization conditions.

\begin{tabular}{|c|c|c|c|c|c|}
\hline \multirow{2}{*}{ Variable } & \multirow{2}{*}{$\begin{array}{l}\text { Optimum } \\
\text { values }\end{array}$} & \multicolumn{2}{|c|}{ Decolorization (\%) } & \multicolumn{2}{|c|}{ TOC removal (\%) } \\
\hline & & Predictive & Experimental & Predictive & Experimental \\
\hline \multicolumn{6}{|c|}{ Decolorization optimization: Only Equation (8) } \\
\hline $\mathrm{H}_{2} \mathrm{O}_{2}, \mathrm{SD}\left(X_{1}\right)$ & 0.96 & & & & \\
\hline Catalyst amount, mg $\left(X_{2}\right)$ & 374.4 & 107.41 & 99.93 & & \\
\hline Impregnated $\mathrm{Fe}, \mathrm{wt} \%\left(X_{3}\right)$ & 9.3 & & & & \\
\hline
\end{tabular}

TOC removal optimization: Only Equation (9)

$\begin{array}{lcccc}\mathrm{H}_{2} \mathrm{O}_{2}, \mathrm{SD}\left(X_{1}\right) & 1.54 & 74.68 & 69.48 \\ \text { Catalyst amount, mg }\left(X_{2}\right) & 391.3 & & \end{array}$

Impregnated $\mathrm{Fe}$, wt\% $\left(X_{3}\right)$

7.7

Decolorization and TOC removal optimization: Equations (8) and (9) simultaneously

The amount of Fe impregnated in the catalyst was set at $5.5 \mathrm{wt} \%$.

$\begin{array}{lccccc}\mathrm{H}_{2} \mathrm{O}_{2}, \mathrm{SD}\left(X_{1}\right) & 3.00 & & & & \\ \text { Catalyst amount, mg }\left(X_{2}\right) & 420 & 88.18 & 86.18 & 71.22 & 66.81 \\ \text { Impregnated Fe, wt\% }\left(X_{3}\right) & 5.5 & & & & \end{array}$

$\mathrm{H}_{2} \mathrm{O}_{2}, \mathrm{SD}\left(X_{1}\right)$ : minimize, Catalyst amount, $\mathrm{mg}\left(X_{2}\right)$ : in range, Impregnated Fe, wt.\% $\left(X_{3}\right)$ : in range. 
Considering that the amount of iron impregnated in the support affects the textural properties and stability of the catalyst (leaching), $5.5 \mathrm{wt} \%$ of impregnated $\mathrm{Fe}$ were set for the multi-objective optimization process. This value guarantees a catalyst specific surface area of $112.0 \mathrm{~m}^{2} / \mathrm{g}$ and leached iron concentration lower than $0.10 \mathrm{mg} / \mathrm{L}$. The desirability predicted by the Design Expert software was 1.00. The error between experimental and predicted values for multi-objective optimization was lower than 2.3 , and $6.6 \%$ for decolorization and TOC removal, respectively. Therefore, it can be concluded that the generated models, using the RSM, are accurate enough to predict the catalytic oxidation of Ponceau $4 \mathrm{R}$ in an aqueous solution using $\mathrm{Fe}(5.5) / \mathrm{Al}-\mathrm{PILC}$ as the catalyst.

The decolorization achieved in the reuse tests of the catalyst decreased with respect to that of the fresh catalyst, passing from $86.18 \%$ in the first oxidation, to 84.15 and $78.19 \%$, in the first and second reuse cycles. TOC removal also decreased with reuse from $66.81 \%$ in the first oxidation, to 63.31 and $59.18 \%$ in cycles one and two of reuse, respectively. The decrease in the catalytic activity of the $\mathrm{Fe}(5.5) / \mathrm{Al}$ PILC with reuse is associated with the accumulation of organic matter over the surface of the catalyst [69].

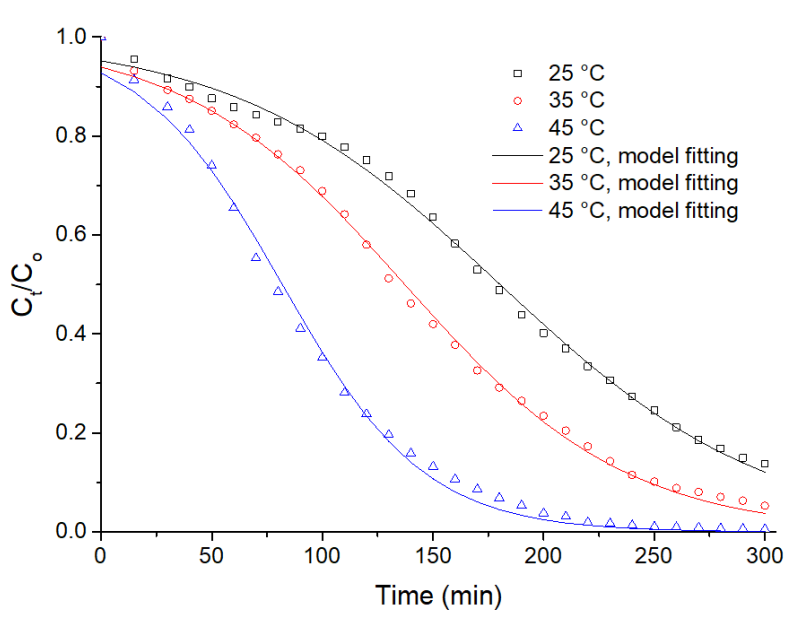

Figure 5. Effect of temperature on the normalized dye concentration evolution. The lines represent the model fitting by the Femi's equation.

\subsection{Kinetic Study of Decolorization}

The kinetic study was carried out under multi-objective optimization conditions (maximum decolorization and maximum TOC removal, corresponding to 3.0 times the stoichiometric dose of $\mathrm{H}_{2} \mathrm{O}_{2}, 420 \mathrm{mg}$ catalyst and 5.5 wt.\% Fe impregnated in Al-PILC). The Ponceau $4 \mathrm{R}$ concentration evolution normalized by the initial concentration at three different temperatures $\left(25,35\right.$ and $\left.45^{\circ} \mathrm{C}\right)$ is shown on Figure 5. Decolorization curves show a sigmoidal profile, typical of catalytic reactions [17], which fits the kinetic model based on the Fermi's equation. This behavior has been observed in other studies on organic compounds degradation, specifically in the degradation of acid orange 7 using a saponite-based catalyst [56], the electro-Fenton oxidation of catechol catalyzed by nano- $\mathrm{Fe}_{3} \mathrm{O}_{4}[70]$ and the azo-dye orange II degradation, using a zeolite Y-Fe [71].

Fermi's equation associates only a few adjustable parameters with intuitive meaning [70]. It is expressed by Equation (11), where $k$ represents the apparent first-order rate constant, and $t^{*}$ is the called transition time, related with the inflection point of the dye concentration curve $[56,70]$ :

$$
\frac{C_{t}}{C_{0}}=\frac{1}{1+\exp \left[k\left(t-t^{*}\right)\right]}
$$

The model described by Fermi's equation was fitted to the normalized dye concentration evolution $\left(C_{t} / C_{0}\right), k$ and $t^{*}$ kinetic parameters (Table 7) were obtained after non-linear regression using an Origin Pro 8.0 software (OriginLab Corporation, USA).

The normalized dye concentration accelerated when increasing temperature, due to the exponential dependence of the kinetic constant on temperature, achieving total decolorization at $45{ }^{\circ} \mathrm{C}$ during the test time $(300 \mathrm{~min})$. For the three temperatures analyzed, the coefficient of determination $\left(\mathrm{R}^{2}\right)$ was greater than 0.9952 , confirming that data fitted the Fermi's equation. Therefore, in the decolorization of Ponceau $4 \mathrm{R}$, an induction period occurred in the initial stage of the reaction, similar to that found in the oxidation of catechol catalyzed by nano$\mathrm{Fe}_{3} \mathrm{O}_{4}$ [70]. When temperature increased from

Table 7. Kinetic parameters obtained using the Fermi's equation.

\begin{tabular}{cccc}
\hline $\mathrm{T}\left({ }^{\circ} \mathrm{C}\right)$ & $k\left(\mathrm{~min}^{-1}\right)$ & $t^{*}(\min )$ & $\mathrm{R}^{2}$ \\
\hline 25 & $0.0166 \pm 2.842 \mathrm{E}-04$ & $180.32 \pm 1.02$ & 0.9967 \\
35 & $0.0200 \pm 3.499 \mathrm{E}-04$ & $137.23 \pm 0.93$ & 0.9973 \\
45 & $0.0312 \pm 9.370 \mathrm{E}-04$ & $81.86 \pm 1.02$ & 0.9952 \\
\hline
\end{tabular}


25 to $35^{\circ} \mathrm{C}$ and from 25 to $45^{\circ} \mathrm{C}$, the value of $k$ increased 1.2 and 1.9 times, respectively. The time required to achieve $50 \%$ of dye decolorization (transition time) decreased when increasing temperature, with $t^{*}=180.32,137.23$ and 81.86 min at 25,35 and $45^{\circ} \mathrm{C}$, respectively.

\section{Conclusions}

The impregnation of the support (Al-PILC) with the iron precursor decreased in $\mathrm{N}_{2}$ adsorption in the microporous region of the catalyst, especially when the iron loading was greater than $5.5 \mathrm{wt} \%$. The XRD patterns of the catalysts did not show the typical peaks of crystalline $\mathrm{Fe}_{2} \mathrm{O}_{3}$ or other forms of iron compounds, suggesting that the iron species were well distributed on the support or in an amorphous state. The effect of the amount of $\mathrm{H}_{2} \mathrm{O}_{2}$, amount of catalyst, and weight percentage of $\mathrm{Fe}$ impregnated in Al-PILC on the heterogeneous Fenton-like oxidation of the dye Ponceau $4 \mathrm{R}$ at $\mathrm{pH} 3.6$ and $25{ }^{\circ} \mathrm{C}$, was successfully evaluated using the response surface methodology (RSM) based on a central composite design (CCD). The amount of iron impregnated in Al-PILC had a positive effect on the decolorization and elimination of TOC, while the amount of $\mathrm{H}_{2} \mathrm{O}_{2}$, expressed as a function of the stoichiometric dose (SD), had a negative effect. Under multiobjective optimization conditions (3.0 times the stoichiometric dose of $\mathrm{H}_{2} \mathrm{O}_{2}, \quad 420 \mathrm{mg}$ $\mathrm{Fe}(\mathrm{wt} \%) / \mathrm{Al}-\mathrm{PILC}$ and $5.5 \mathrm{wt} \% \mathrm{Fe}$ impregnated in Al-PILC), it was possible to achieve $88.18 \%$ decolorization and $66.81 \%$ TOC removal after 5 $\mathrm{h}$ of reaction at $25^{\circ} \mathrm{C}$, with the additional advantage of showing an iron leaching of less than $0.10 \mathrm{mg} / \mathrm{L}$.

A semi-empirical kinetic model based on Fermi's equation was used to describe the normalized dye concentration evolution as a function of temperature $\left(25,35\right.$, and $\left.45^{\circ} \mathrm{C}\right)$. An increase in temperature from 25 to $45{ }^{\circ} \mathrm{C}$ decreased the time required to achieve $50 \%$ of decolorization (transition time, $t^{*}$ ) from 180.32 to 81.26 min. The oxidation of Ponceau 4R using an aluminum pillared clay impregnated with iron as catalyst, was found to be an efficient method for the decolorization and TOC removal of aqueous solutions containing this colorant.

\section{Acknowledgment}

The authors gratefully acknowledge the financial support of Universidad Nacional de Colombia sede Manizales through the DIMAUNAL projects (Code 38621 and 46078).

\section{References}

[1] Al-Degs, Y., Khraisheh, M.A.M., Allen, S.J., Ahmad, M.N.A. (2001). Sorption behavior of cationic and anionic dyes from aqueous solution on different types of activated carbons. Sep. Purif. Technol., 36, 91-102. DOI: 10.1081/SS-100000853

[2] Kim, S., Park, C.M., Jang, M., Son, A., Her, N., Yu, M., Snyder, S., Kim, D.-H., Yoon, Y. (2018). Aqueous removal of inorganic and organic contaminants by graphene-based nanoadsorbents: A review. Chemosphere, 212, $\begin{array}{lllllllllllllll}1 & 1 & 0 & 4 & - & 1 & 1 & 2 & 4 & & \text { D } & \text { O } & \text { I : }\end{array}$ 10.1016/j.chemosphere.2018.09.033

[3] Deng, Y., Zhao, R. (2015). Advanced Oxidation Processes (AOPs) in Wastewater Treatment. Curr. Pollut. Rep., 1, 167-176. DOI: 10.1007/s40726-015-0015-z

[4] Salazar-Arias, Á.M., Giraldo-Gómez, G.I., Sanabria-González, N.R. (2020). Degradation of phenol using mill scale as a Fenton-type catalyst. Water Environ. J., 34, 183-191. DOI: 10.1111/wej. 12516

[5] Pignatello, J.J., Oliveros, E., MacKay, A. (2006). Advanced oxidation processes for organic contaminant destruction based on the Fenton reaction and related chemistry. Crit. Rev. Environ. Sci. Technol., 36, 1-84. DOI: 10.1080/10643380500326564

[6] Bonora, R., Boaretti, C., Campea, L., Roso, M., Martucci, A., Modesti, M., Lorenzetti, A. (2020). Combined AOPs for formaldehyde degradation using heterogeneous nanostructured catalysts. Nanomaterials, 10, 148. DOI: 10.3390/nano10010148

[7] Ma, J., Song, W., Chen, C., Ma, W., Zhao, J., Tang, Y. (2005). Fenton degradation of organic compounds promoted by dyes under visible irradiation. Environ. Sci. Technol., 39, 58105815. DOI: $10.1021 / \mathrm{es} 050001 \mathrm{x}$

[8] Walling, C. (1975). Fenton's reagent revisited. Acc. Chem. Res., 8, 125-131. DOI: 10.1021/ar50088a003

[9] Walling, C., Goosen, A. (1973). Mechanism of the ferric ion catalyzed decomposition of hydrogen peroxide. Effect of organic substrates. J. Am. Chem. Soc., 95, 2987-2991. DOI: 10.1021/ja00790a042

[10] Zárate-Guzmán, A.I., González-Gutiérrez, L.V., Godínez, L.A., Medel-Reyes, A., Carrasco-Marín, F., Romero-Cano, L.A. (2019). Towards understanding of heterogeneous Fenton reaction using carbon-Fe catalysts coupled to in-situ $\mathrm{H}_{2} \mathrm{O}_{2}$ electro-generation as clean technology for wastewater treatment. Chemosphere, 224, 698-706. DOI: 10.1016/j.chemosphere.2019.02.101 
[11] He, J., Yang, X., Men, B., Wang, D. (2016). Interfacial mechanisms of heterogeneous Fenton reactions catalyzed by iron-based materials: A review. J. Environ. Sci., 39, 97-109. DOI: $10.1016 /$ j.jes.2015.12.003

[12] Sreeja, P.H., Sosamony, K.J. (2016). A comparative study of homogeneous and heterogeneous photo-Fenton process for textile wastewater treatment. Proc. Technol., 24, 217-223. DOI: 10.1016/j.protcy.2016.05.065

[13] Ikhlaq, A., Brown, D.R., Kasprzyk-Hordern, B. (2013). Mechanisms of catalytic ozonation: An investigation into superoxide ion radical and hydrogen peroxide formation during catalytic ozonation on alumina and zeolites in water. Appl. Catal. B: Environ., 129, 437-449. DOI: $10.1016 / \mathrm{j}$. apcatb.2012.09.038

[14] Ferroudj, N., Nzimoto, J., Davidson, A., Talbot, D., Briot, E., Dupuis, V., Bée, A., Medjram, M.S., Abramson, S. (2013). Maghemite nanoparticles and maghemite/silica nanocomposite microspheres as magnetic Fenton catalysts for the removal of water pollutants. Appl. Catal. B: Environ., 136-137, 9-18. DOI: 10.1016/j.apcatb.2013.01.046

[15] Maurya, M.R., Titinchi, S.J.J., Chand, S. (2003). Oxidation of phenol with $\mathrm{H}_{2} \mathrm{O}_{2}$ catalysed by $\mathrm{Cr}$ (III), $\mathrm{Fe}$ (III) or $\mathrm{Bi}(\mathrm{III}) \mathrm{N}, \mathrm{N}^{\prime}$ bis (salicylidene)diethylenetriamine $\left(\mathrm{H}_{2}\right.$ saldien) complexes encapsulated in zeoliteY. J. Mol. Catal. A: Chem., 193, 165-176. DOI: 10.1016/S1381-1169(02)00451-X

[16] Zazo, J.A., Casas, J.A., Mohedano, A.F., Rodríguez, J.J. (2006). Catalytic wet peroxide oxidation of phenol with a Fe/active carbon catalyst. Appl. Catal. B: Environ., 65, 261268. DOI: $10.1016 /$ j.apcatb.2006.02.008

[17] Ramirez, J.H., Costa, C.A., Madeira, L.M., Mata, G., Vicente, M.A., Rojas-Cervantes, M.L., López-Peinado, A.J., Martín-Aranda, R.M. (2007). Fenton-like oxidation of Orange II solutions using heterogeneous catalysts based on saponite clay. Appl. Catal. B: Enviro $n$. , $71, \quad 44-56$. D O I : 10.1016/j.apcatb.2006.08.012

[18] Herney-Ramirez, J., Lampinen, M., Vicente, M.A., Costa, C.A., Madeira, L.M. (2008). Experimental design to optimize the oxidation of Orange II dye solution using a clay-based Fenton-like catalyst. Ind. Eng. Chem. Res., 47, 284-294. DOI: 10.1021/ie070990y

[19] Bertella, F., Pergher, S.B.C. (2015). Pillaring of bentonite clay with $\mathrm{Al}$ and Co. Micropor. Mesopor. Mater., 201, 116-123. DOI: 10.1016/j.micromeso.2014.09.013

[20] Figueras, F. (1988). Pillared clays as catalysts. Catal. Rev., 30, 457-499. DOI: 10.1080/01614948808080811
[21] Gil, A., Gandía, L.M., Vicente, M.A. (2000). Recent advances in the synthesis and catalytic applications of pillared clays. Catal. Rev., 42, 145-212. DOI: doi.org/10.1081/CR100100261

[22] Oliveira, L.C.A., Lago, R.M., Fabris, J.D., Solar, C., Sapag, K. (2003). Transition metals supported on Al-PILCs as catalysts for $\mathrm{C}_{6} \mathrm{H}_{5} \mathrm{Cl}$ oxidation. Braz. J. Chem. Eng., 20, $45-50$. DO I : $10.1590 / \mathrm{S} 0104$ 66322003000100009

[23] Thiam, A., Brillas, E., Garrido, J.A., Rodríguez, R.M., Sirés, I. (2016). Routes for the electrochemical degradation of the artificial food azo-colour Ponceau 4R by advanced oxidation processes. Appl. Catal. B: Environ., $180, \quad 227-236$. D O I : 10.1016/j.apcatb.2015.06.039

[24] Benincá, C., Peralta-Zamora, P., Tavares, C.R.G., Igarashi-Mafra, L. (2013). Degradation of an azo dye (Ponceau 4R) and treatment of wastewater from a food industry by ozonation. Ozone: Sci. Eng., 35, 295-301. DOI: 10.1080/01919512.2013.794691

[25] Ghoneim, M.M., El-Desoky, H.S., Zidan, N.M. (2011). Electro-Fenton oxidation of Sunset Yellow FCF azo-dye in aqueous solutions. Desalination, 274, 22-30. DOI: 10.1016/j.desal.2011.01.062

[26] Arroyave Rojas, J.A., Rodríguez Gaviria, E.M., Barón Aristizábal, C.A., Moreno Salazar, C.C. (2012). Degradation and mineralization of the ponceau red dye by the use of the Fenton reagent. Rev. P+L., 7, 48-58.

[27] Thiam, A., Sirés, I., Brillas, E. (2015). Treatment of a mixture of food color additives (E122, E124 and E129) in different water matrices by UVA and solar photoelectro-Fenton. Water Res., 81, 178-187. DOI: 10.1016/j.watres.2015.05.057

[28] Macías-Quiroga, I.F., Rojas-Méndez, E.F., Giraldo-Gómez, G.I., Sanabria-González, N.R. (2020). Experimental data of a catalytic decolorization of Ponceau 4R dye using the cobalt (II) $/ \mathrm{NaHCO}_{3} / \mathrm{H}_{2} \mathrm{O}_{2}$ system in aqueous solution. Data Brief., 30, 105463. DOI: 10.1016/j.dib.2020.105463

[29] Rueda Márquez, J.J., Levchuk, I., Sillanpää, M. (2018). Application of catalytic wet peroxide oxidation for industrial and urban wastewater treatment: A review. Catalysts, 8, 1-18. DOI: $10.3390 /$ catal 8120673

[30] Macías-Quiroga, I.F., Giraldo-Gómez, G.I., Sanabria-González, N.R. (2018). Characterization of Colombian clay and its potential use as adsorbent. Sci. World J., 2018, 1-11. DOI: 10.1155/2018/5969178 
[31] Day, P.R. (1965). Particle fractionation and particle-size analysis. In Black, C.A., Evans, D.D., Ensminger, L.E., White, J.L., Clarck, F.E. (Eds.) Methods of Soil Analysis, Part 1. Physical and Mineralogical. Madison: American Society of Agronomy, Inc. Publisher.

[32] Ge, Z., Li, D., Pinnavaia, T.J. (1994). Preparation of alumina-pillared montmorillonites with high thermal stability, regular microporosity and Lewis/Brönsted acidity. Microporous Mater., 3, 165-175. DOI: 10.1016/0927-6513(94)00020-4

[33] Carriazo, J.G., Guelou, E., Barrault, J., Tatibouët, J.M., Moreno, S. (2003). Catalytic wet peroxide oxidation of phenol over $\mathrm{Al}-\mathrm{Cu}$ or Al-Fe modified clays. Appl. Clay Sci., 22, 303308. DOI: 10.1016/S0169-1317(03)00124-8

[34] Galeano, L.A., Gil, A., Vicente, M.A. (2010). Effect of the atomic active metal ratio in $\mathrm{Al} / \mathrm{Fe}-, \quad \mathrm{Al} / \mathrm{Cu}-$ and $\mathrm{Al} /(\mathrm{Fe}-\mathrm{Cu})$-intercalating solutions on the physicochemical properties and catalytic activity of pillared clays in the CWPO of methyl orange. Appl. Catal. B: Environ., $100, \quad 271-281$. DOI : 10.1016/j.apcatb.2010.08.003

[35] Cañizares, P., Valverde, J.L., Sun Kou, M.R., Molina, C.B. (1999). Synthesis and characterization of PILCs with single and mixed oxide pillars prepared from two different bentonites. A comparative study. Micropor. Mesopo. Mater., 29, 267-281. DOI: 10.1016/S13871811(98)00295-9

[36] Gregg, S.J., Sing, K.S.W. (1982). Adsorption, Surface Area and Porosity. Second ed. London: Academic Press.

[37] Rouquerol, F., Rouquerol, J., Sing, K. (1999). Adsorption by Powders and Porous Solids. London: Academic Press.

[38] Torres-Luna, J.A., Carriazo, J.G., Sanabria, N.R. (2016). Delaminated montmorillonite with iron(III)- $\mathrm{TiO}_{2}$ species as a photocatalyst for removal of a textile azo-dye from aqueous solution. Environ. Technol., 37, 1346-1356. DOI: 10.1080/09593330.2015.1114031

[39] Sanabria, N.R., Centeno, M.A., Molina, R., Moreno, S. (2009). Pillared clays with $\mathrm{Al}-\mathrm{Fe}$ and $\mathrm{Al}-\mathrm{Ce}-\mathrm{Fe}$ in concentrated medium: Synthesis and catalytic activity. Appl. Catal. A: Gen., $\quad 356, \quad 243-249$. D O I : 10.1016/j.apcata.2009.01.013

[40] Rueda Márquez, J.J., Levchuk, I., Sillanpää, M. (2018). Application of catalytic wet peroxide oxidation for industrial and urban wastewater Treatment: A review. Catalysts, 8, 1-18. DOI: 10.3390/catal8120673
[41] Banković, P., Milutinović-Nikolić, A., Mojović, Z., Jović-Jovičić, N., Žunić, M., Dondur, V., Jovanović, D. (2012). Al,Fe-pillared clays in catalytic decolorization of aqueous tartrazine solutions. Appl. Clay Sci., 58, 73-78. DOI: 10.1016/j.clay.2012.01.015

[42] Ramírez, J.H., Galeano, L.A., Pinchao, G., Bedoya, R.A., Hidalgo, A. (2018). Optimized CWPO phenol oxidation in CSTR reactor catalyzed by Al/Fe-PILC from concentrated precursors at circumneutral pH. J Environ Chem Eng , $\quad 6, \quad 2429-2441$. D O I : 10.1016/j.jece.2018.02.024

[43] Gómez-Obando, V.A., García-Mora, A.-M., Basante, J.S., Hidalgo, A., Galeano, L.-A. (2019). CWPO degradation of methyl orange at circumneutral $\mathrm{pH}$ : Multi-response statistical optimization, main intermediates and byproducts. Front. Chem., 7, 1-15. DOI: 10.3389/fchem.2019.00772

[44] Ribeiro, R.S., Rodrigues, R.O., Silva, A.M.T., Tavares, P.B., Carvalho, A.M.C., Figueiredo, J.L., Faria, J.L., Gomes, H.T. (2017). Hybrid magnetic graphitic nanocomposites towards catalytic wet peroxide oxidation of the liquid effluent from a mechanical biological treatment plant for municipal solid waste. Appl. Catal. B: Environ., 219, 645-657. DOI: 10.1016/j.apcatb.2017.08.013

[45] Ordoñez-Ordoñez, A., Revelo-Romo, D.M., Garcia-Mora, A.M., Hidalgo-Troya, A., Galeano, L.-A. (2019). MS2 coliphage inactivation by $\mathrm{Al} / \mathrm{Fe}$ PILC-activated catalytic wet peroxide oxidation: multiresponse statistical optimization. Heliyon, 5, e01892. DOI: 10.1016/j.heliyon.2019.e01892

[46] Yabalak, E., Topaloğlu, İ., Gizir, A.M. (2019). Multi-response central composite design of the mineralization and removal of aniline by subcritical water oxidation method. Int. J. Ind. Chem., 10, 97-105. DOI: 10.1007/s40090019-0175-6

[47] Izadiyan, P., Hemmateenejad, B. (2016). Multi-response optimization of factors affecting ultrasonic assisted extraction from Iranian basil using central composite design. Food Chem., 190, 864-870. DOI: 10.1016/j.foodchem.2015.06.036

[48] Turhan, G.D., Kartal, O.E. (2010). PhotoFenton treatment of C.I. reactive black 5 by use of response surface methodology. Fresenius Environ. Bull., 19, 2736-2743.

[49] Mousavi, S.A., Nazari, S. (2017). Applying response surface methodology to optimize the fenton oxidation process in the removal of reactive red 2. Pol. J. Environ. Stud., 26, 765772. DOI: $10.15244 /$ pjoes/65365 
[50] Dean, A., Voss, D., Draguljić, D. (2017). Response Surface Methodology. In Dean, A., Voss, D., Draguljić, D. (Eds.) Design and Analysis of Experiments. Cham - Switzerland: Springer International Publishing.

[51] Bergaya, F., Aouad, A., Mandalia, T. (2006). Chapter 7.5 Modified Clays and Clay Minerals. In Bergaya, F., Theng, B.K.G., Lagaly, G. (Eds.) Developments in Clay Science. Oxford: Elsevier Science.

[52] Ramsey, M.H., Potts, P.J., Webb, P.C., Watkins, P., Watson, J.S., Coles, B.J. (1995). An objective assessment of analytical method precision: comparison of ICP-AES and XRF for the analysis of silicate rocks. Chem. Geol., 124, 1-19. DOI: 10.1016/0009-2541(95)00020$\mathrm{M}$

[53] Tireli, A.A., do Rosário Guimarães, I., Mello Mattos de Castro, G., Gonçalves, M.A., de Castro Ramalho, T., Guerreiro, M.C. (2020). Iron and molybdenum mixed oxide supported on Al-PILC for the catalytic oxidative desulfurization of dibenzothiophene in simulated diesel fuel. Environ. Sci. Pollut. Res., 27, 1496314976. DOI: 10.1007/s11356-020-07961-8

[54] Zhang, T., Liu, J., Wang, D., Zhao, Z., Wei, Y., Cheng, K., Jiang, G., Duan, A. (2014). Selective catalytic reduction of $\mathrm{NO}$ with $\mathrm{NH}_{3}$ over HZSM-5-supported $\mathrm{Fe}-\mathrm{Cu}$ nanocomposite catalysts: The $\mathrm{Fe}-\mathrm{Cu}$ bimetallic effect. Appl. $\mathrm{Ca}$ tal. B: Environ., 148-149, 520-531. DOI: 10.1016/j.apcatb.2013.11.006

[55] Qian, W.-y., Su, Y.-x., Yang, X., Yuan, M.-h., Deng, W.-y., Zhao, B.-t. (2017). Experimental study on selective catalytic reduction of NO with propene over iron based catalysts supported on aluminum pillared clays. J. Fuel Chem. Technol., 45, 1499-1507. DOI: 10.1016/S1872-5813(17)30067-1

[56] Herney-Ramirez, J., Silva, A.M.T., Vicente, M.A., Costa, C.A., Madeira, L.M. (2011). Degradation of acid orange 7 using a saponitebased catalyst in wet hydrogen peroxide oxidation: Kinetic study with the Fermi's equation. Appl. Catal. B: Environ., 101, 197-205. DOI: $10.1016 /$ j.apcatb.2010.09.020

[57] Qi, G., Yang, R.T. (2005). Selective catalytic oxidation (SCO) of ammonia to nitrogen over Fe/ZSM-5 catalysts. Appl. Catal. A: Gen., 287, 25-33. DOI: 10.1016/j.apcata.2005.03.006

[58] Karimifard, S., Alavi Moghaddam, M.R. (2018). Application of response surface methodology in physicochemical removal of dyes from wastewater: A critical review. Sci. Total Environ., 640-641, 772-797. DOI: 10.1016/j.scitotenv.2018.05.355
[59] Castro-Castro, J.D., Macías-Quiroga, I.F., Giraldo-Gómez, G.I., Sanabria-González, N.R. (2020). Adsorption of Cr(VI) in aqueous solution using a surfactant-modified bentonite. Sci. World J., 2020, 1-9. DOI: 10.1155/2020/3628163

[60] Özdikicierler, O., Yemişçioğlu, F., Saygın Gümüşkesen, A. (2016). Effects of process parameters on 3-MCPD and glycidyl ester formation during steam distillation of olive oil and olive pomace oil. Eur. Food Res. Technol., 242, 805-813. DOI: 10.1007/s00217-015-25877

[61] Sarrai, A.E., Hanini, S., Merzouk, N.K., Tassalit, D., Szabó, T., Hernádi, K., Nagy, L. (2016). Using central composite experimental design to optimize the degradation of tylosin from aqueous solution by photo-Fenton reaction. Materials, 9, 428. DOI: 10.3390/ma9060428

[62] Arslan-Alaton, I., Tureli, G., Olmez-Hanci, T. (2009). Treatment of azo dye production wastewaters using Photo-Fenton-like advanced oxidation processes: Optimization by response surface methodology. J. Photochem. Photobiol. A: Chem., 202, 142-153. DOI: 10.1016/j.jphotochem.2008.11.019

[63] Zhou, X., Zhou, S., Feng, X. (2017). Optimization of the photoelectrocatalytic oxidation of landfill leachate using copper and nitrate codoped $\mathrm{TiO}_{2}(\mathrm{Ti})$ by response surface methodology. PLOS ONE, 12, 1-18. DOI: 10.1371/journal.pone.0171234

[64] Ardekani, P.S., Karimi, H., Ghaedi, M., Asfaram, A., Purkait, M.K. (2017). Ultrasonic assisted removal of methylene blue on ultrasonically synthesized zinc hydroxide nanoparticles on activated carbon prepared from wood of cherry tree: Experimental design methodology and artificial neural network. J. Mol. Liq. , $\quad 229, \quad 114-124$. D O I : 10.1016/j.molliq.2016.12.028

[65] Spadaro, J.T., Isabelle, L., Renganathan, V. (1994). Hydroxyl radical mediated degradation of azo dyes: evidence for benzene generation. Environ. Sci. Technol., 28, 1389-1393. DOI: 10.1021/es00056a031

[66] Lin, S.-S., Gurol, M.D. (1998). Catalytic decomposition of hydrogen peroxide on iron oxide: Kinetics, mechanism, and implications. Environ. Sci. Technol., 32, 1417-1423. DOI: 10.1021/es970648k

[67] Carriazo, J., Guélou, E., Barrault, J., Tatibouët, J.M., Molina, R., Moreno, S. (2005). Catalytic wet peroxide oxidation of phenol by pillared clays containing $\mathrm{Al}-\mathrm{Ce}-\mathrm{Fe}$. Water Res., $39, \quad 3891-3899$. D O I : 10.1016/j.watres.2005.06.034 
[68] Pérez-Moya, M., Graells, M., del Valle, L.J., Centelles, E., Mansilla, H.D. (2007). Fenton and photo-Fenton degradation of 2chlorophenol: Multivariate analysis and toxicity monitoring. Catal. Today, 124, 163-171. DOI: 10.1016/j.cattod.2007.03.034

[69] Cao, G.-m., Sheng, M., Niu, W.-f., Fei, Y.-l., Li, D. (2009). Regeneration and reuse of iron catalyst for Fenton-like reactions. J. Hazard. Mater., 172, 1446-1449. DOI: 10.1016/j.jhazmat.2009.08.010
[70] Hou, B., Han, H., Jia, S., Zhuang, H., Xu, P., Wang, D. (2015). Heterogeneous electroFenton oxidation of catechol catalyzed by nano- $\mathrm{Fe}_{3} \mathrm{O}_{4}$ : kinetics with the Fermi's equation. J. Taiwan Inst. Chem. Eng., 56, 138147. DOI: $10.1016 /$ j.jtice.2015.04.017

[71] Rache, M.L., García, A.R., Zea, H.R., Silva, A.M.T., Madeira, L.M., Ramírez, J.H. (2014). Azo-dye orange II degradation by the heterogeneous Fenton-like process using a zeolite YFe catalyst-Kinetics with a model based on the Fermi's equation. Appl. Catal. B: Environ., $146, \quad 192-200$. D O I : 10.1016/j.apcatb.2013.04.028. 